\title{
THE COMPARISON OF OPRAH SHOWS FROM THE THEORY OF CONVERSATIONAL STYLES AND PREFERENCE STRUCTURE
}

\author{
Sylvia; Ienneke Indra Dewi \\ English Literature Department, Faculty of Humanities, BINUS University \\ Jln. Kemanggisan Ilir III No. 45, Kemanggisan/Palmerah, Jakarta Barat 11480
}

\begin{abstract}
This paper intends to compare the conversational styles and the preference structure between Oprah shows in FRIENDS which is in a group guest and J.K. Rowling in a single guest. The data were taken from two different videos of Oprah transcribed and analysed. In FRIENDS edition, the conversational style is high considerateness style and in J.K. Rowling edition is high involvement style. The conversation in FRIENDS edition is relatively slower than in J.K. Rowling edition. Oprah as the host uses high involvement style in both editions. In FRIENDS edition, the first part of pairs that mostly occurs is question which the second part is expected answer, while J.K. Rowling is assessment which the second part is agreement. It means that they prefer using positive response rather than negative response.
\end{abstract}

Keywords: comparison, conversation analysis, conversational style, characteristics of conversational style, preference structure

\begin{abstract}
ABSTRAK
Tulisan ini bertujuan untuk membandingkan gaya percakapan dan struktur preferensi antara acara Oprah, dengan FRIENDS sebagai grup tamu dan JK Rowling sebagai tamu tunggal. Data diambil dari dua video yang berbeda dari Oprah ditranskripsi dan dianalisis. Dalam edisi FRIENDS, gaya percakapan adalah gaya kepekaan tinggi dan JK Rowling edisi adalah gaya keterlibatan tinggi. Percakapan dalam edisi FRIENDS relatif lebih lambat daripada di edisi JK Rowling. Oprah sebagai pembawa acara menggunakan gaya keterlibatan tinggi di kedua edisi. Pada edisi FRIENDS, bagian pertama dari pasangan yang sebagian besar terjadi adalah pertanyaan dari jawaban bagian kedua yang diharapkan, sedangkan JK Rowling merupakan penilaian kesepakatan bagian kedua. Artinya, mereka memilih respons positif daripada respons negative.
\end{abstract}

Kata kunci: perbandingan, analisis percakapan, gaya percakapan, karakteristik gaya percakapan, struktur preferensi 


\section{INTRODUCTION}

A conversation has an important role in our lives. By having a conversation, we can communicate and have some interactions with each other. Nowadays, a host of a TV show must have a good conversation in order to have good interactions with the audience. A host should lead the talk show in order that the conversations run smoothly and become interesting to watch and listen. In conversations including talkshows, a lot of things such as pauses i.e. people stop talking for a while; overlap i.e. both speakers and listeners speak together might happen. This kind of conversational styles would influence the atmosphere of the conversations and would determine whether the success of the purpose of the conversation in the talk show.

The conversation also depends on the host's experiences, whether they are new hosts or the experienced ones. The hosts who have much experience usually increase their conversations and study again to response the guest or achieve their goal in every show. In the conversation, the host must know the conversation sequence whether the guest agrees or disagrees, accepts or refuses about something that they talk. The guests also hesitate in responding the host question. For example:

Host: where you will hold your wedding party Angelina Jolie?

(1.5 second)

Host: Hmm-

Jolie: Em-well- it need so much time to talk about this.

The example above is representing the guest response which is included to the dispreferred response with initial hesitation. The guest hesitates to let the host and the public knows where she wants to hold her wedding party. It is because she is one of popular artist who has privacy. She does not want her special wedding party to be exposed by some of journalists that are always searching the news of popular artist.

Oprah Winfrey show hosted by Oprah Gail Winfrey is a talk show program in America, which has been shown from 1986 until now. The show has been successful and has a highest rating in almost 24 years shown not only in America but also all around the world.

This paper would present the conversational styles and preference structure and their specific features used in the Oprah Winfrey shows in FRIENDS (20 November 2003) in which Oprah had a discussion with a group of people and in JK ROWLINGS (October 1, 2010) in which there were only two person having the conversation i.e. Oprah and one person. The transcript and videos of the Oprah shows were downloaded and the characteristics of the conversational styles and elements for preference structure were classified and analysed. The conversational styles were classified into high involvement and high considerateness style, and then counted the amount of the characteristics and preference structure that occurs. Then the analysis based on the conversation analysis theory was presented.

\section{Conversational Styles}

Conversational styles are divided into high involvement style and high considerate styles (Beaumont, 2000; Yule, 2008). Yule mentions that in high involvement style, people speak faster than usual and there are a lot of interruption or overlap as well as fast turn taking. The conversation contains emotion which determines the faster rate of the speech.

Wray and Bloomer (2006) said that fast rate of speech can be marked by using right and left carats $(>$ word $<$ ). Beaumont (2000) said that the person who uses high involvement style features, especially faster turn taking and overlap usually will interrupt another turn. On the other hand the 
other style i.e. high considerateness style has the opposite features compared to the high involvement styles. In short Beaumont (2000) describes that high considerateness style "consists of slower speech, slower turn taking, longer pauses between turns and an avoidance of simultaneous speech” (p. 2). Wray and Bloomer (2006) said that the slower rate of speech in high considerateness style is indicated by a degree signs (superscript circle ${ }^{0}$ word $^{0}$ ) and Jefferson (2004) added that a degree sign is indicated the softer sound than usual. Therefore, falling and slowly intonation of speaker's voice is use to count slow rate of speech.

According to Yule (2008), if two speakers having different styles meet, in which the first speaker uses high involvement style and the second speaker uses high considerateness style, the conversation can be opposed. High considerateness condition is inverted with high involvement style. As it was mentioned before high involvement style is faster than high considerateness style, so the negative perception of high considerateness style appeared. However, the negative perception of high involvement style also appears in high considerateness speaker. High considerateness speaker assumed that high involvement which begin the conversation or turn faster can be seen as noisy, aggressive, selfish, forceful, and even annoying.

\section{Turn Taking}

In the conversation, the speakers do not speak all at the same time. They usually wait for their turn. For example, there are two speakers in a conversation. Speaker A begins to talk and stop, then speaker B starts, talks, and stops. Thus, the rule of the conversation is A-B-A-B-A-B (Levinson, 1983). Villain (2003) said that turns are distributed in two ways which are "current speaker selection and self-selection.” The current speaker directly selects next speaker by making request, asking question, or issuing invitations and offers (p. 113).

Downes (1998) described the organization of turn taking in conversation or Sacks's rules by using chart as in Figure 1.

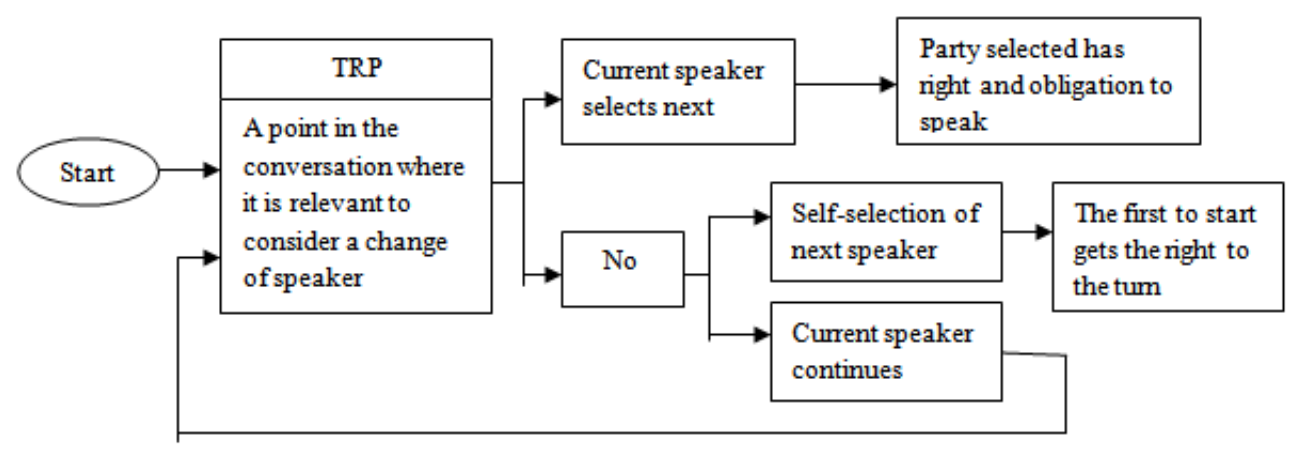

Figure 1 The organization of Sacks' rules

Finegan (1999) said that competition is occurred in a conversation. A speaker in a conversation may give his or her floor or raising his or her volume and continue their turn of speaking to defend their turn.

In conversations, in turn taking, some events such as pauses, overlaps and interruptions may happen. Pauses is the short stop happening when a speaker is in doubt or need to consider what to say next (Finegan, 1999; Yule, 2008). There are short and long pauses. According to Wray and Bloomer (2006), short pauses are marked by a dot in bracket (.), which indicates the length of pause is less than a second and long pause can be marked as (2.3), which is indicated the length of pause is more than a second. E.g. short pauses. 
A: So (.) do you think that you will finish your assignment on time?

B: Not really (.) but (.) I believe I will.

In the example above, B pauses when he wants to say the next activity that he would be able to finish his assignment on time. He thinks what to say next. B answers it by hesitation about the assignment and he makes sure that he can get it.

Below is the example of long pause between A and B:

A: B, what happen with you? You look worried.

A: B, is there something you're worried about?

B: No, I just have a problem with my father. (1.8) I think I need your advice.

In the example of long pause above, A repeats her question to B. It is because when A is waiting for B answer, B does not directly respond to A question. When B answers A question after A repeats it, B also does long pause in the middle of B's turn because B thinks what to say next.

Overlap is defined as "If more than one participant tries to talk at the same time, one of them usually stops" (Yule, 2006, p.128). Overlap also happens when the next speaker thinks that current speaker's turn is completed, so the next speaker begins to speak. In other words, the current speaker has come to a point where what is being said is completely heard, it sounds like the speaker might be finished, so next speaker beginning to talk and current speaker continues to speak. Overlap is also an action where two voices are going at once which the words from the second speaker overlap the last or part of the words from the first speaker (Cutting, 2008, p.29).

Wray and Bloomer (2006) said that:

"Where one person begins when someone else is already speaking, use a single opening square bracket ([ ) before the new speaker's words, aligned vertically with another at the appropriate point in the established speaker's line (p.188).

Here the example of overlap:

A: This food is delicious [Yeah, it's very delicious.

B: [What food that you eat?

In the example above, the last words of " $A$ " is overlapped with the first word of " $B$ ". The overlap words are heard at the same time. Speaker "B" thinks that speaker "A" turn is completed because " $A$ " said her sense of that food. When " $A$ " wants to emphasize that food is really delicious, speaker " $B$ " with his curiosity wants to know the food that speaker " $A$ " eat.

Yule (2008) said that interruption occurs when two of speakers do overlap by competing for the floor. The next speaker begins to speak when the current speaker stops his or her floor and follows what the next speaker says (p. 74).

In a conversation, the next speakers cannot be sure when the current speaker's turn is completed, but next speaker usually cuts the conversation of current speaker. It is because next speaker does not want to wait until he or she get the floor, thus interruption happens (Cutting, 2008). Jefferson (2004) said that moment when the interruption begins is indicated with double oblique (//) which the next speaker cuts current speaker turn.

For example:

A: The singer is very //

B: // beautiful. Yeah, she is beautiful. 
Look at the example above, speaker "B" cut or interrupt what speaker "A" said. Speaker "B" also does not giving a chance to "A" to finish his or her floor. Therefore, speaker "A" does not finish his or her turn and her turn is cut by speaker " $\mathrm{B}$ " and speaker " $\mathrm{B}$ " finishes that turn.

\section{Preference structure}

Yule (2008) explained that basically the first part which contains a request is made by expectation that the second part will be an acceptance. Generally, an acceptance is more likeable than a refusal. This condition is called preference. In preference structure, this second part of pairs which the part for responding first part is divided into two, they are preferred response and dispreferred response (p.78).

Some kinds of adjacency pairs are marked by preference for a particular type of second part. For instance, invitations, requests, and questions have preferred response (positive) and dispreferred response (negative) answer as the second part (Finegan, 1999, p.313). In this case, preferred response means the positive responses from the hearer as expected by the speaker, while dispreferred means the negative responses i.e. the unexpected responses from the hearer,

According to Levinson (1983, p.336), he indicated the general patterns of preferred and dispreferred responses.

Table 1 The general patterns of preferences structure

\begin{tabular}{ccc}
\hline First Part & \multicolumn{2}{c}{ Second Part } \\
\cline { 2 - 3 } & Preferred Response & Dispreferred Response \\
\hline Request & Acceptance & Refusal \\
Offer and Invitation & Acceptance & Refusal \\
Assessment & Agreement & Disagreement \\
Question & Expected answer & Unexpected answer / non answer \\
Proposal & Agreement & Disagreement \\
\hline
\end{tabular}

Yule (2008) gives some other examples of the styles usually used in order to express dispreferred response second turn, as in Table 2.

Table 2 The pattern of dispreferred response

\begin{tabular}{lll}
\hline \multicolumn{2}{c}{ How to do a dispreferred response } & \multicolumn{1}{c}{ Examples } \\
\hline a. & Delay or hesitate & pause; er; em; ah \\
b. $\quad$ Preface & well; oh \\
c. $\quad$ Express doubt & I'm not sure; I don't know \\
d. $\quad$ Token Yes & That'a great; I'd love to \\
e. $\quad$ Apology & I'm sorry; what a pity \\
f. $\quad$ Mention obligation & I must do X; I'm expected in Y \\
g. & Appeal for understanding & You see; you know \\
h. & Make it non-personal & Everybody else; out there \\
i. & Give an account & Too much work; no time left \\
j. & Use mitigators & Really; mostly; sort of; kinda \\
k. & Hedge the negative & I guess not; not possible \\
\hline
\end{tabular}


Dispreferred response the second part can be indicated by a pause and begins with hesitation elements such as well or uh. It is different with preferred response second part which indicates the response without a pause and use simple structured second part. Dispreferred response the second part also begins with the use an expression of appreciation or apology or state the acceptance or agreement, and finally accompanied by an explanation (Finegan, 1999).

Thus, analyzing conversational style would offer deeper horizons on how people manage the conversation through various features, in order to have the intended communication situations.

The study of conversational analysis has been done by Christine (2009) entitled "Conversation Analysis on News Interview with Barrack Hussein Obama: a Pragmatic Approach.” She focused her study on conversation analysis in news interviews. She used Barrack Hussein Obama as her subject of analysis. She also used library and field research to make her analysis done. She wanted to find the conversational style of Barrack Hussein Obama and his responses in news interview with Bill O' Reilly. She used four videos of interview with four topics and also transcribed the conversation of interview. She used conversation analysis theory and some elements such as pauses, overlap, backchannel, and latch to investigate conversational style of Barrack Hussein Obama. As the result of her analysis, she found that the conversational style of Barrack Hussein Obama is high involvement style and he used minimal responses also elaboration in answer the question which he gave direct questions to the answer. However, this research would compare two kinds of groups, first is person to person (FRIEND) and person to group (JK ROWLING) and investigate the preference structures of the two. Another study on interruption and overlap done by Kristian (2007).

She investigated the interruption and overlap utterances produced by the host and hostess in Ceriwis a TV show and the reason the reason why they interrupted and overlapped each others. She found that the total number of utterances containing overlaps is greater than utterances containing interruptions. She also found that the host was interrupted more than the hostess and the overlap was done by the host and hostess together. One of the reasons of interruption in the program that she found is completing. The other reasons are repeating, making a clarification, answering, and informing. Then, the reason of overlap that she found is showing closeness and solidarity. She also concluded that interruptions and overlaps in this program cannot be categorized as violation of talk, because the host and hostess did it to show the cooperation in brought the program. This paperfocuses on conversational style and preference structure the theory that is used not only interruption and overlap, but also another part of conversation analysis theory.

\section{RESULTS AND DISCUSSION}

The data from Oprah show videos of FRIENDS and J.K. Rowling edition were used to find out the data of conversational style. The transcription was done using transcribing orthographically theory. As for, the preference structure, the theory of Levinson (1983) is applied.

The transcription in this paper used to analyse the conversations applies Jefferson (2004) and Wray and Bloomer (2006)'s symbols that are used in the conversations. The indicators of conversational style used are:

$>$ word<
${ }_{\text {o }}$ word $^{\circ}$
(FT)
$(\mathrm{ST})$
$($.
$(2.3)$
[
$/ /$

\author{
Fast rate of speech \\ Slow rate of speech \\ Fast Turn Taking \\ Slow Turn Taking \\ Short Pause \\ Long pause \\ Overlap \\ Interruption
}




\section{Conversational Styles}

Conversational styles i.e high involvement style and high considerateness style of Oprah Show in FRIENDS and J.K. Rowling edition are different. The results of the high involvement style consisting of fast rate of speech, fast turn taking, an avoidance of inter turn pauses (short pause), and frequent initiations of simultaneous speech can be seen in table 3 .

Table 3 High Involvement Style in FRIENDS edition

\begin{tabular}{|c|c|c|c|c|c|c|}
\hline \multirow[t]{2}{*}{ Segments } & \multicolumn{5}{|c|}{ High Involvement Style } & \multirow[t]{2}{*}{ Total } \\
\hline & $\begin{array}{l}\text { Fast } \\
\text { Rate }\end{array}$ & $\begin{array}{l}\text { Fast } \\
\text { Turn }\end{array}$ & $\begin{array}{l}\text { Short } \\
\text { Pause }\end{array}$ & Overlap & Interruption & \\
\hline FRIENDS member & 0 & 2 & 7 & 0 & 2 & 11 \\
\hline Favorite moment & 5 & 7 & 5 & 4 & 3 & 24 \\
\hline $\begin{array}{l}\text { Life change off } \\
\text { camera }\end{array}$ & 1 & 6 & 4 & 3 & 3 & 17 \\
\hline $\begin{array}{l}\text { Wish for each } \\
\text { other }\end{array}$ & 3 & 1 & 0 & 0 & 1 & 5 \\
\hline Backstage tour & 0 & 6 & 2 & 5 & 1 & 14 \\
\hline \multicolumn{6}{|c|}{ Total of high involvement style } & 71 \\
\hline
\end{tabular}

The duration of FRIENDS video is 41.32 minutes, which is divided into five segments, they are FRIENDS member, favorite moment, life change off camera, wish for each other, and backstage tour. In the first segment with the duration of 08.05 minutes, it happens 11 times of high involvement style's characteristics. Then in the second segment with the duration of 16.23 minutes, it happens 24 times of high involvement style's characteristics. Afterwards, 17 times of high involvement style's characteristics occurs in the third segment with the duration of 07.51 minutes. Then during 04.05 minutes of the fourth segment, 5 times of high involvement style's characteristics happened. The last in 04.47 minutes in the fifth segment, 14 times of high involvement style's characteristics happened. Therefore, the total of high involvement style that occurs in FRIENDS edition is 71.

The example of short pauses in FRIENDS edition:

Oprah: I want to ask you all this. I know I have a bunch of questions about who is... Okay? Who's gonna have the hardest time, do you think, on the final taping day? The hardest time... (1.5)

Matt: Jennifer. (0.8)

Oprah: Jennifer? (0.5)

Lisa: $\quad$ No, 'cause she's getting it out now.

Jennifer: I'm gonna be still on that night. I think that Matty may have a hard time.

Matthew: The last night here will be really tough on me.

Oprah: Who is the funniest? Who is the funniest? (0.5)

Courteney: Matthew Perry?

Jennifer: Matty Perry! (1.3)

The example above happened when Oprah wanted to ask them about "who is" question. FRIENDS's actors and actress did short pause to think the answer that Oprah gave about "Who is the funniest? Who is the funniest?." Courteney did short pause before she gave the answer about who is the funniest. Short pause is also used to wait until the turn of the current speaker finished. It can be seen when Jennifer said Matty Perry! Matthew waited until the current speaker finished speaking or in other words he waited for his turn. It looked when Oprah asked "who is the funniest?" and Courteney answered Matty Perry first and did Jennifer. Therefore, looking from this case, Matty Perry waited for his turn. 
Table 4 High Involvement Style in J.K. Rowling edition

\begin{tabular}{|c|c|c|c|c|c|c|}
\hline \multirow[t]{2}{*}{ Segments } & \multicolumn{5}{|c|}{ High Involvement Style } & \multirow[t]{2}{*}{ Total } \\
\hline & $\begin{array}{l}\text { Fast } \\
\text { Rate }\end{array}$ & $\begin{array}{l}\text { Fast } \\
\text { Turn }\end{array}$ & $\begin{array}{l}\text { Short } \\
\text { Pause }\end{array}$ & Overlap & Interruption & \\
\hline Rowling's book & 8 & 4 & 5 & 3 & 1 & 21 \\
\hline Harry in JK's life & 3 & 6 & 0 & 2 & 4 & 15 \\
\hline $\begin{array}{l}\text { Money, famous, } \\
\text { and religious }\end{array}$ & 4 & 12 & 10 & 8 & 4 & 38 \\
\hline Rowling's life & 1 & 11 & 4 & 3 & 8 & 27 \\
\hline Harvard speech & 5 & 15 & 5 & 9 & 6 & 40 \\
\hline \multicolumn{6}{|c|}{ Total of high involvement style } & 141 \\
\hline
\end{tabular}

Oprah show in J.K. Rowling edition is divided into 5 segments which have been already mentioned before in the table above. The show is held during 40.30 minutes. In the 09.25 minutes of first segment, high involvement style's characteristics that occurs is 21 times. Then, in the second segment with the duration of 05.30 minutes, it occurs 15 times of high involvement style's characteristics. In 06.20 minutes of the third segment, 38 times of high involvement style's characteristics occur. Then, in the fourth segment with the duration of 08.37 minutes, 27 times of high involvement style's characteristics appear. And the last in the duration 10.20 minutes of fifth segment, 40 high involvement style's characteristics occur. Therefore, the total of high involvement style that appear in J.K. Rowling edition is 141.

The interesting segment in FRIENDS and J.K. Rowling edition, can be seen from the mostly characteristics of high involvement style that occur. In FRIENDS edition, the interesting segment is in the second segment which Oprah and her FRIENDS guest talk about favorite moment that happened when they made the serial of FRIENDS. As for in J.K. Rowling edition, the interesting segment is when Oprah and Rowling talk about speaking in public. Based on the mostly characteristics of high involvement style that occur in the interesting segment between Oprah in FRIENDS and J.K. Rowling, the high involvement style can be used in the segment when they talk about the unforgetable experience.

The characteristics of high involvement style support to find out how many high involvement styles that occur in FRIENDS and J.K. Rowling edition. Thus, based on the high involvement style in table 3.1 and table 3.2, also the total that occur in each edition, the high involvement style that occur in J.K. Rowling edition is bigger than FRIENDS edition. It is because the conversation with single guest response more quickly than in group guest. In the conversation between Oprah and Rowling, the topic is only about Rowling and it made them focus on responding the conversation directly. It is different in FRIENDS which in responding Oprah question, they must wait first because the topic of conversation that Oprah gives is for the entire member in FRIENDS.

The characteristics of high considerateness style are slow rate of speech, slow turn taking, longer pauses between turns, and avoid of overlap or interruption. The results of those items can be seen in Table 5. 
Table 5 High Considerateness Style in FRIENDS edition

\begin{tabular}{|c|c|c|c|c|c|}
\hline \multirow[t]{2}{*}{ Segments } & \multicolumn{4}{|c|}{ High Considerateness Style } & \multirow[t]{2}{*}{ Tota } \\
\hline & $\begin{array}{l}\text { Slow } \\
\text { Rate }\end{array}$ & $\begin{array}{c}\text { Slow } \\
\text { Turn Taking }\end{array}$ & Long Pauses & $\begin{array}{l}\text { Avoid overlap / } \\
\text { interruption }\end{array}$ & \\
\hline FRIENDS member & 0 & 19 & 12 & 19 & 50 \\
\hline Favorite moment & 5 & 15 & 10 & 15 & 45 \\
\hline Life change off camera & 0 & 5 & 1 & 5 & 11 \\
\hline Wish for each other & 0 & 1 & 1 & 1 & 3 \\
\hline Backstage tour & 0 & 2 & 0 & 2 & 4 \\
\hline \multicolumn{5}{|c|}{ Total of high considerateness style } & 113 \\
\hline
\end{tabular}

Table 5 shows the high considerateness style in FRIENDS edition. In the first segment, 53 times of the characteristics of high considerateness style occur during 08.05 minutes. Then in 16.23 minutes of the second segment, 45 times of high considerateness style characteristics appear. In the third segment with the duration of 07.51 minutes, it occurs 11 times characteristics of high considerateness style. During 03.65 minutes of the fourth segment, 3 times of high considerateness style characteristics occur. And the last is in the fifth segment which during 04.47 minutes the characteristics of high considerateness style occur. Therefore, the total of high considerateness styles that appear in FRIENDS edition is 113.

In J.K. Rowling edition, high considerateness styles that appear are:

Table 6 High considerateness style in J.K. Rowling edition

\begin{tabular}{|c|c|c|c|c|c|}
\hline \multirow[t]{2}{*}{ Segments } & \multicolumn{4}{|c|}{ High Considerateness Style } & \multirow[t]{2}{*}{ Total } \\
\hline & $\begin{array}{l}\text { Slow } \\
\text { Rate }\end{array}$ & $\begin{array}{c}\text { Slow } \\
\text { Turn Taking }\end{array}$ & $\begin{array}{l}\text { Long } \\
\text { Pauses }\end{array}$ & $\begin{array}{l}\text { Avoid Overlap / } \\
\text { Interruption }\end{array}$ & \\
\hline J.K. Rowling's book & 5 & 6 & 1 & 6 & 18 \\
\hline $\begin{array}{l}\text { Harry } \\
\text { Rowling life }\end{array}$ & 1 & 3 & 3 & 3 & 10 \\
\hline $\begin{array}{l}\text { Money, famous, and } \\
\text { religious }\end{array}$ & 3 & 13 & 3 & 13 & 32 \\
\hline J.K. Rowling life & 0 & 9 & 5 & 9 & 23 \\
\hline Harvard speech & 1 & 11 & 6 & 11 & 29 \\
\hline \multicolumn{5}{|c|}{ Total of high considerateness style } & 112 \\
\hline
\end{tabular}

Table 6 represents the amount of high considerateness styles appear in J.K. Rowling edition. During 09.25 minutes of the first segment, it happens 18 times of high considerateness style's characteristics. In the second segment which the duration of 05.30 minutes, 10 times of high considerateness style's characteristics appear. 32 times of high considerateness style's characteristics occur in the third segment by duration 06.20 minutes. Then in the fourth segment with the duration of 08.37 minutes, 23 times of high considerateness style's characteristics happen. Then in the last segment, which the duration of 10.20 minutes, 31 times of high considerateness style's characteristics occur. Therefore, the total of high considerateness in J.K. Rowling edition is 112.

Example of long pauses in high considerateness styles. Next is the example of long pauses in J.K. Rowling edition:

Oprah: Do you think you'll ever make peace? (0.9)

Rowling: No, I don't. I don't. I think that it's such a huge thing to be estranged from a parent that obviously you would - it would have to be very big reasons for that.

Oprah: Do you have your reasons? 
Rowling: I have my reasons.

Oprah: Any you want to share? (2.3)

Rowling: It wasn't a good relationship from my point of view for a very long time but I had a need to please and I kept that going for a long time and then there - there just came a point at which I had to pull-up and say I can't do this anymore. And, yeah...//

Oprah: $\quad$ // Do you regret that he can't be a part of this success? (2.8)

Rowling: Well, the estrangement happened post-success so he was - he was there for a while. If I'm totally honest with you I regret much more that my mother never saw any of it. That - that's a bit of a killer. I mean she would have just - //

Oprah: // Would she have loved reading it? (1.6)

Rowling: I can honestly say I know a hundred percent she would have adored it. Yeah. Yeah.

Based on the conversation above, Oprah started her question by using long pause which Oprah's question is related to Rowling's personal life. Oprah asked Rowling whether she would make peace with her father or not. Rowling answered it by using short pause first and gave the answer that she did not want to make peace. Rowling also used long pause when Oprah asked her to share about the reason why she did not want to make peace with her father. Then, Rowling started it by silence during 2.3 seconds of pause and then she gave the reason. Look from the example, both Oprah and Rowling did long pause when Oprah asked something private to Rowling and when Rowling wanted to answer Oprah's question that connected to her personal life. Rowling might think first before she started to speak, it is because Oprah show would be watched by the public in any countries.

The mostly characteristics of high considerateness style that occur in FRIENDS edition is in the first segment which it tells about FRIENDS member. In this segment, Oprah and her group guest talks each other about the member of FRIENDS and it needs time to think between all of them. They also try to avoid overlap and interruption during answer Oprah's question. Then in J.K. Rowling edition the mostly characteristics of high considerateness style occur in the third segment which it talks about money, famous and religious things. It happens when Oprah asks something personal to Rowling and vice versa. That segment is too personal and sensitive to talk. Both of them must think to answer and respond it. Thus, high considerateness style can happen in conversation when the topic of conversation is too personal and it needs time to respond it.

According to Table 5 and Table 6, which these tables describe about high considerateness style that occur in FRIENDS and J.K. Rowling edition, the total of high considerateness style that appear in FRIENDS edition is bigger than in J.K. Rowling edition. It is because in FRIENDS edition, the guest is in group. Thus, they do the conversation relatively slow than in J.K. Rowling. In group, between host and each guest are waiting to answer and response each other statement.

\section{Preference Structure}

In daily conversation, someone usually gives response to let or inform the other speaker know that we still hear and respond what they said. Current speaker usually gives the request, offer or invitation, assessment, question, and propose about something. Sometimes next speaker can accept or agree and refuse or disagree as the respond of what current speaker say. The respond of the next speaker can be preferred (positive) or dispreferred (negative) and it acts as the second part of pairs. And to support the finding of preference structure whether it is preferred response or dispreferred response, the first part of pairs in conversation is used. First part and second part of pairs in conversation are occurring in every conversation which the first part is from the current speaker and the second part is the next speaker to respond what the current speaker said.

The overall results of the preference structure in FRIENDS edition can be seen in Table 3.5 and in JK ROWLING in Table 3.6. 
Table 7 Preference structure in FRIENDS edition

\begin{tabular}{ccc}
\hline First part & Preferred response & $\begin{array}{c}\text { Dispreferred } \\
\text { response }\end{array}$ \\
\hline Request & 10 & 0 \\
Offer and invitation & 6 & 2 \\
Assessment & 22 & 13 \\
Question & 52 & 27 \\
Proposal & 2 & 1 \\
Total & 92 & 43 \\
\hline
\end{tabular}

Table 7 shows the amount of preferred response in FRIENDS edition is bigger than the dispreferred response. It happens 92 times of preferred response and 43 times of dispreferred response in the conversation of the video. The finding of preferred response and dispreferred response is supported by the first part of pairs in the preference structure. The biggest first part of pairs in the conversation is from the expected answer of question which it happens 52 times of pairs in the conversation. Thus, it shows that both Oprah and her guests in group choose the positive response rather than negative response. They do the conversation well in the talk show, and make the show run well. In this edition, almost all of the first part of pairs in the conversation appears and it is different with J.K. Rowling edition.

\section{e.g. $\quad$ Request (acceptance)}

The acceptance of request occurs when Oprah wants her guest to do something.

Oprah: Alright David, do me a favour and describe each cast member in ways that we wouldn't know.

David: Le Blanc, I've always thought of as like blue collar, like show up every time, every day on time. He's a hundred percent. Always got your bet. He's the guy you want, like, if you get in a fight in a bar, he's the guy you want... And just in terms of...

The conversation is between Oprah and David. Oprah asked David to describe FRIENDS members to the audiences. Without any hesitation, he explained FRIENDS member and it began by describing Le Blanc first.

\section{Offer and Invitation (acceptance - refusal)}

The acceptance of offering and invitation can be seen in the example below:

Oprah: No, you're almost done. You're almost done. You're okay.

Jennifer: ${ }^{0}$ Yeah? ${ }^{0}$

Oprah: $\quad$ You're okay. (2.3)

Jennifer: ${ }^{\circ}$ Seriously? ${ }^{\circ}$

Oprah: Yeah. Okay, no really. Okay, want to take a minute? Okay.

The example of the acceptance of offering above is shown when Oprah offered Jennifer to take a minute. It is because Jennifer felt emotional when she wanted to explain about her cast mates. Oprah thought that Jennifer needed time to calm herself down and then she could continue to explain again about her cast mates. Therefore, Oprah offered Jennifer to make her self calm first. Then, without the response from Jennifer, it marked that Jennifer accept Oprah offering. 
Table 8 Preference structure in J.K. Rowling edition

\begin{tabular}{lcc}
\hline First Part & Preferred response & Dispreferred response \\
\hline Offer and invitation & 0 & 1 \\
Assessment & 47 & 14 \\
Question & 29 & 22 \\
Proposal & 1 & 0 \\
\hline Total & 77 & 37 \\
\hline
\end{tabular}

In J.K. Rowling edition, the kinds of preference structure that mostly occur is preferred response. During 40.30 minutes of the video's duration, it occurs 77 times of preferred response and it bigger than the dispreferred response. Then, the first part of pairs that mostly occur in the conversation between Oprah and J.K. Rowling is the agreement of assessment which it happens 47 times of pairs in the conversation.

\section{Offer and invitation (refusal)} below.

Offering or invitations appear rarely in J.K. Rowling edition. It can be seen in the conversation

Oprah: Any you want to share? (2.3)

Rowling: It wasn't a good relationship from my point of view for a very long time but I had a need to please and I kept that going for a long time and then there - there just came a point at which I had to pull-up and say I can't do this anymore. And, yeah...//

The part of the conversation above represented Oprah's offering to ask Rowling whether she wanted to share about the reason why she did not want to make peace with his father. This conversation or topic is too personal to Rowling, because she said that "That's never an easy thing to do in the public eye, but there you are". Rowling showed her refusal by hesitating and pausing before delivering the answer "(2.3) it wasn't a good...” The dispreferred response signal also happens in the middle when Rowling tried to continue it "then there (pause) there...", thus pause and self-editing happens in there. She did not really want to share about the reason because it was hard to her.

\section{Question (expected - unexpected answer)}

In J.K. Rowling edition the expected answer of question also supports the preferred structures that occur. In this part, Oprah as the host who usually gives the question to Rowling, she gets the expected answer of her question. The expected answer of question can be easily answered by Rowling. It is because the question is appropriate to her to answer as a guest.

Oprah: // Would she have loved reading it? (1.6)

Rowling: I can honestly say I know a hundred percent she would have adored it. Yeah. Yeah.

Oprah: But you started writing before she [passed?

Rowling: [Yeah, but I never told her about it.//

Oprah: // You never told her?

Rowling: And I would have done. You know? I would have told her about it and I know she would have really liked it. I think she was - I think it was six months before she died I started writing. Yeah, and I never shared it with her. So that //

Oprah: // Do you regret that? 
Rowling: Yeah, hugely. Hugely. But the odd thing is that that's just life, isn't it? The books wouldn't be what they are if she hadn't died. I mean her death is on virtually every other page of the Harry Potter books, you know? At least half of Harry's journey is a journey to deal with death in its many forms, what it does to the living, what it means to die, what survives death - it's there in every [single volume of the books.

Oprah: [What the love of your parents - the love of you parents. How that abides with you still. Yes.

Rowling: Exactly, exactly. Exactly. So, if she hadn't died I don't think it's too strong to say there wouldn't be Harry Potter. There wouldn't - you know? The books are what they are because she died. Because I loved her and she died. That's why they are what they are.

In the conversation above, Oprah gave J.K. Rowling question which Rowling's responsed it by positive response. The question that Oprah gave to her can be easily answered by Rowling. In this case, Oprah asked Rowling about the time when she wrote the book and the connectivity with Rowling's parents. Rowling answered Oprah's question directly because it showed her love of her parents especially to Rowling's mother. Therefore, Rowling did not hesitate to answer it and gave the positive response.

The unexpected answer of question can be seen in the conversation between Oprah and J.K. Rowling. Here the example of unexpected answer of question in this edition.

Oprah: //So, didn't you know?

Rowling: No.

Oprah: Wasn't there part of you - [subconsciously, that knew?

Rowling: [Part of me -

Oprah: Yes.

Rowling: I - I remember once and it was like - it was like - well, like - I'm going to call it clash - a flash of clairvoyance now. Obviously if it hadn't come true it would just be some crazy thought I had. But I do remember one day, writing Philosopher's Stone, I was walking away from the café where I'd been working on -

The example above showed about unexpected answer of question. It could be seen when Oprah asked Rowling about her statement that "one day every child in the world will know his name." after hearing that statement, Oprah asked Rowling and she answered it by dispreferred response signal, such as pause (delay) then answered Oprah's question. Rowling also did the same thing in the next question. In this conversation, she answered Oprah question by long pause (delay) first "I-(2.0) I remember once..." then it continued with Rowling's hesitation, because she corrected what she said "It was like-it was like". Then to show more about her unexpected answer of Oprah's question, she used well and like- (preface) which it is marked as dispreferred response.

The dominant of preference structures that occurs in this edition is preferred response which it shows the use of positive response is more active rather than the dispreferred response. Then, the first part of pairs that mostly occur is assessment which in giving their opinion about something, both Oprah and Rowling agree about the opinion or statement that they give.

The summary of the analysis about the comparison of conversational style and preference structure on Oprah show in FRIENDS and J.K. Rowling edition, can be seen in the table below. 
Table 9 Summary of analysis

\begin{tabular}{|c|c|c|c|}
\hline No. & Aspects & $\begin{array}{c}\text { FRIENDS } \\
\text { (group guest) }\end{array}$ & $\begin{array}{l}\text { J.K. Rowling } \\
\text { (single guest) }\end{array}$ \\
\hline \multirow[t]{3}{*}{1} & Conversational style & & \\
\hline & - High involvement style & 71 & 141 \\
\hline & - High considerateness style & 113 & 112 \\
\hline \multirow[t]{3}{*}{2} & Oprah’s conversational style & & \\
\hline & • High involvement style & 21 & 71 \\
\hline & - High considerateness style & 18 & 54 \\
\hline \multirow[t]{15}{*}{3} & Preference structure & & \\
\hline & - $\quad$ Preferred response & & \\
\hline & - Request & 10 & - \\
\hline & - $\quad$ Offer/invitation & 6 & - \\
\hline & - $\quad$ Assessment & 22 & 47 \\
\hline & - Question & 52 & 29 \\
\hline & - $\quad$ Proposal & 2 & 1 \\
\hline & Total & 92 & 77 \\
\hline & - Dispreferred response & & \\
\hline & - Request & - & - \\
\hline & - $\quad$ Offer/invitation & 2 & 1 \\
\hline & - $\quad$ Assessment & 13 & 14 \\
\hline & - Question & 27 & 22 \\
\hline & - $\quad$ Proposal & 1 & - \\
\hline & Total & 43 & 37 \\
\hline
\end{tabular}

The first aspect that is analyzed is about the conversational style between Oprah show in FRIENDS and J.K. Rowling edition. Conversational style is divided into two; they are high involvement style and high considerateness style. The analysis of the conversational style is supported by using the characteristics of each style, which the characteristics of high involvement style are fast rate of speech, fast turn taking, short pause, overlap, and interruption. Meanwhile, the characteristics of high considerateness style are slow rate of speech, slow turn taking, long pause, and then avoid overlap and interruption. In FRIENDS edition, the total of high considerateness style characteristics that occur is bigger than the total of high involvement style characteristics that occur, because the conversation is in a group and the conversation run slower than in a single guest. In the other hand in J.K. Rowling edition the total of high involvement style characteristics is bigger than the total of high considerateness style characteristic, because the conversation only focus on one person. Thus, the conversation that Oprah do with her single guest is faster than in her group guest.

Here the second aspect being analyzed, about the preference structures that occurs in FRIENDS and J.K. Rowling edition. Preference structure is divided into two; they are preferred and dispreferred response. In the conversation, preferred response or dispreferred response is act as second part of pairs and to support the find out of the preference structures that occur, the first part of pairs in the conversation is used. Based on the analysis, preferred response mostly appears in FRIENDS and J.K. Rowling edition rather than the dispreferred response. Then, the most first parts of pairs that support the preferred response are different in both editions. In FRIENDS, the first part of pairs that mostly occur is question because by giving many questions to FRIENDS members, it can make the members participate in the show. Meanwhile, in J.K. Rowling edition, the first part of pairs that mostly occur is assessment because the conversation is between two persons and it is easy to reveal the topic by giving the opinion about something of the conversation; it also makes the conversation more interesting. 


\section{CONCLUSION}

People can interact with each other by doing a conversation. The conversational style can find in the conversation itself and also in the person who participate the conversation. High involvement style and high considerateness style appears in every conversation, but the style is depending on the characteristics that often occur in the conversation. In this paper studies the comparison of two of Oprah Winfrey shows in different guest which are in a group guest (FRIENDS) and in a single guest (J.K. Rowling). In comparing the conversational styles of Oprah show in FRIENDS and J.K. Rowling edition, the data show that both high involvement style and high considerateness style occcur. In FRIENDS edition, the dominant conversational style is high considerateness style. Therefore, the high involvement style is smaller than the high considerateness style. It is because when the conversation is in group or more than two persons, the style is relatively slow in the conversation. In that condition, there is not only one person that responds the host question, however it has six persons who interact in the conversation. Thus, Oprah show in FRIENDS edition needs much time to respond the conversation between each other. They need longer time to think something and because the conversation is in a group, they wait for their turn or in other words, they wait until the current speaker finish to speak. However, in J.K. Rowling edition, the high involvement style is bigger than high considerateness style. It is because Oprah speaks with her single guest and it only focuses on one person. In this edition, between Oprah and J.K. Rowling talk more about unforgettable experience. They can achieve the interesting conversation and it makes them more in using overlap and interruption. Therefore, the conversation that they do is relatively fast than in the group.

Regarding the preference structure in FRIENDS and J.K. Rowling edition, the second part of pairs or the response that is used in both editions is similar. They use positive response (preferred response) in responding Oprah questions or statements to make the show success. It is because by using preferred response or positive response in the show, the show can continue until the show finish. However, if the use of dispreferred response is more than the preferred response, it can make the show or the conversation run slowly and it seems that the guests do not want to share something in the show. By refusing or disagreeing about that, the interesting conversation in the show cannot be found. However, to support the preference structure whether it is preferred response or dispreferred response, the first parts of pairs are used in both editions are different. In FRIENDS edition, the use of question is more active than in J.K Rowling edition. It is because the conversation is not only focuses on one person, but it focuses on 6 persons. As the host, Oprah must have some questions to the guests, so the 6 members of FRIENDS could participate in the conversation. Meanwhile, in Oprah show with her single guest (J.K. Rowling), the assessment appears more than another first part of pairs. It is because the conversation that they do is only focuses on one person which is between Oprah and Rowling. Therefore, both of them are more representing their opinion or statement rather than give the questions.

\section{REFERENCES}

Beaumont, S. L. (2000). Conversational style of mother and their preadolescent and middle adolescent daughter. Retrieved March 8, 2011, from http://findarticles.com

Christine. (2009). Conversation analysis on news interview with Barrack Hussein Obama: a pragmatic approach. Unpublished thesis. Jakarta: Bina Nusantara University.

Cutting, J. (2008). Pragmatic and discourse: A resource book for student. New York: Routledge. 
Downes, W. (1998). Language and society. New York: Cambridge University Press.

Finegan, E. (1999). Language (Its Structure and Use). USA: Hacourt Brace College.

Jefferson, G. (2004). Glossary of Transcript Symbol. In G. H. Lerner, Conversation Analysis: Studies from the First Generation (pp. 24-31). Amsterdam/Philadelphia: John Benjamins Publishing Company.

Kristian. T.T. (2007). Interruption and overlap produced by the host and hostess of Ceriwis in Trans TV. Unpublished thesis. Surabaya: Petra Christian University

Levinson, S. C. (1983). Pragmatics. New York: Cambridge University Press.

Sacks, H. (2004). The Organization of Turn-Taking in Conversation. In G. H. Lerner, Conversation Analysis: Studies from the First Generation (pp. 35-42). Amsterdam: John Benjamins Publishing Company.

Villain, N. B. (2003). Language, Culture, and Communication. New Jersey: Pearson Education.

Wray, A., \& Bloomer, A. (2006). Projects in Linguistics. New York: Oxford University Press.

Yule, G. (2008). Pragmatics. United States: Oxford University Press.

Yule, G. (2006). The Study of Language. New York: Cambridge University Press. 